\title{
Pengaruh Terapi Dzikir terhadap Intensitas Nyeri pada Pasien Gastritis
}

\author{
Fadli $^{1}$, Resky $^{2}$, Andi Sastria ${ }^{3}$ \\ ${ }^{1}$ Program Studi Profesi Ners, STIKES Muhammadiyah Sidrap, Indonesia \\ ${ }^{2,3}$ Program Studi Ilmu Keperawatan, STIKES Muhammadiyah Sidrap, Indonesia \\ Email: fadlietri@gmail.com
}

\begin{abstract}
Effect of Dzikir Therapy on Pain Intensity in Gastritis Patients. The digestive system is a food/nutrition pathway from the entrance or input to output (excretion/elimination). Anatomically the digestive system or often called the digestive or gastrointestinal system consists of various kinds of organs from the oral cavity to the anus. Complaints in gastrointestinal patients can be related to local/intralumen disorders of the gastrointestinal tract for example the presence of duodeni ulcers, gastritis and so on. The purpose of this study was to determine the effect of dzikir therapy on pain intensity in gastritis patients. The study used a quasy experiment design with the Pre and Post Test Group design approach. This research was conducted from June to August 2018. Data collection in the Surgical Room of Nene Mallomo Hospital, Sidrap Regency was conducted every morning starting June 2, 2018 to August 25, 2018 with a total sample of 45 respondents. The results of this study found that $\mathrm{p}=0,000$ with a significance level of $\mathrm{p}<\alpha(0.05)$ where $\mathrm{p}<\alpha$ so can be concluded that there is an effect of dzikir therapy on pain intensity in gastritis patients at Nene Mallomo Hospital, Sidrap Regency.
\end{abstract}

Keywords: Dzikir therapy, Gastritis, Pain intensity

\begin{abstract}
Abstrak: Pengaruh Terapi Dzikir terhadap Intensitas Nyeri pada Pasien Gastritis. Sistem pencernaan merupakan suatu saluran jalan makanan/nutrisi dari jalan masuk atau input sampai dengan keluaran (ekskresi/eliminasi). Secara anatomis sistem pencernaan atau sering disebut sistem digestivus atau gastrointestinal terdiri atas berbagai macam organ dari rongga mulut sampai anus. Keluhan pada pasien gastrointestinal dapat berkaitan dengan gangguan lokal/intralumen saluran cerna misalnya adanya ulkus duodeni, gastritis dan sebagainya. Tujuan penelitian ini adalah untuk mengetahui pengaruh terapi dzikir terhadap intensitas nyeri pada pasien gastritis. Penelitian tersebut mengunakan desain quasi experiment dengan pendekatan Pre and Post Test Group design. Penelitian ini dilakukan pada bulan Juni sampai dengan Agustus 2018. Pengumpulan data di Ruang Bedah Rumah Sakit Nene Mallomo Kabupaten Sidrap dilaksanakan setiap pagi mulai tanggal 2 Juni 2018 sampai dengan 25 Agustus 2018 dengan jumlah sampel sebanyak 45 responden. Hasil penelitian ini diperoleh nilai $p=0,000$ dengan tingkat kemaknaan $p<\alpha(0,05)$ yang dimana nilai $p<\alpha$ maka dapat disimpulkan bahwa ada pengaruh terapi dzikir terhadap intensitas nyeri pada pasien gastritis di rumah sakit Nene Mallomo Kabupaten Sidrap.
\end{abstract}

Kata kunci: Terapi dzikir, Gastritis, Intensitas nyeri

\section{PENDAHULUAN}

Gastritis merupakan terjadinya inflamasi pada mukosa lambung yang disertai kerusakan atau erosi pada mukosa (Diyono \& Mulyanti, 2013). Tanda dan gejala dari pada penyakit gastritis seperti nyeri ulu hati, anoreksia, mual, muntah, sakit kepala, perut kembung, rasa asam di mulut, hemorhagi, kolik usus dan diare (Nuratif \& Kusuma, 2015).

Menurut World Health Organization (WHO), insiden gastritis di dunia sekitar 1,8-2,1 juta dari jumlah penduduk setiap tahunnya, di Inggris (22\%), China (31\%), Jepang (14,5\%), Kanada (35\%), dan Perancis $(29,5 \%)$, serta di
Asia Tenggara sekitar 583.635 dari jumlah penduduk setiap tahunnya. Presentase dari angka kejadian gastritis di Indonesia menurut World Health Organization (WHO) adalah 40,8\%. Angka kejadian gastritis pada beberapa daerah di Indonesia cukup tinggi dengan prevalensi 274,396 kasus (Wahyuni, Rumpiati, \& Lestariningsih, 2017).

Berdasarkan data dari Dinas Kesehatan Propinsi Sulawesi Selatan kasus gastritis pada tahun 2014 sebanyak 29.465 kasus, pada tahun 2015 meningkat menjadi 35.159 kasus, dan pada tahun 2016 gastritis berada pada urutan ke-5 setelah penyakit infeksi saluran pernafasan atas, hipertensi esensial, dermatitis eksim, penyakit 
pulpa dan penyakit periapikal, dengan jumlah kasus sebanyak 30.167 kasus (Dinkes Prop. Sulsel, 2015).

Studi pendahuluan yang dilakukan oleh peneliti di Ruang Rawat Inap Rumah Sakit Nene Mallomo Kabupaten Sidenreng Rappang menunjukkan bahwa angka kejadian gastiritis, pada tahun 2015 adalah sebanyak 1.612 kasus, sedikit menurun pada tahun 2016 menjadi sebanyak 1.314 kasus, tetapi kemudian meningkat kembali pada tahun 2017 menjadi sebanyak 1.509 kasus. Sementara untuk tahun 2018 pada bulan Januari sampai April saja, sebanyak 299 kasus telah dicatat.

Berdasarkan angka kejadian tersebut, salah satu tindakan keperawatan yang dapat dilakukan untuk mengurangi nyeri pada pasien gastritis yaitu tekhnik distraksi, diantaranya distraksi visual, taktil, audiotori, dan intelektual. Salah satu contoh distraksi auditori yaitu dengan terapi dzikir (Yuniarti, Darwin, \& Huda, 2016).

Secara fisiologis, terapi spiritual dengan berdzikir atau mengingat asma Allah akan menyebabkan otak bekerja. Ketika otak mendapat rangsangan dari luar, maka otak akan memproduksi zat kimia yang akan memberi rasa nyaman yaitu neuropeptida. Setelah otak memproduksi zat tersebut, maka zat ini akan menyangkut dan diserap didalam tubuh yang kemudian akan memberi umpan balik berupa kenikmatan atau kenyamanan (Budiyanto, Ma'rifah, \& Susanti, 2015).

Penelitian yang dilakukan oleh (Rudyana \& Bangun (2014)menyatakan adanya pengaruh terapi dzikir (Asmaul Husna) terhadap skala intensitas nyeri pasien post operasi laparatomi. Analisa data yang digunakan yaitu uji MannWhitney didapatkan $(p=0,001)$ yang berarti ada perbedaan penurunan intensitas nyeri yang signifikan antara sesudah diberikan intervensi terapi dzikir (Asmaul Husna) pada kelompok intervensi dengan kelompok kontrol.

Penelitian terkait terapi dzikir sangat penting dilakukan dalam penanganan terapi non farmakologi. Seperti yang telah dilakukan oleh beberapa peneliti terdahulu hanya memberikan terapi pada kasus-kasus pasca operasi dalam menurunkan skala nyeri. Pada penelitian ini, peneliti mencoba pada pasien yang menderita gastritis dalam menurunkan intensitas nyerinya. Penelitian terkait terapi dzikir masih jarang dilakukan di lokasi penelitian. Terapi yang sering digunakan hanya terapi relaksasi napas dalam, maka peneliti ingin menerapkan hal yang baru sehingga bisa dijadikan sebagai salah satu terapi non farmakologi.
Tujuan penelitian diketahui pengaruh terhadap intensitas nyeri pada pasien gastritis dengan mengunakan intervensi keperawatan berupa terapi dzikir. Manfaat dari penelitian ini adalah sebagai sumber informasi dalam pengembangan ilmu keperawatan dalam meningkatkan pemahaman perawat tentang teknik distraksi berupa terapi dzikir agar digunakan sebagai salah satu intervensi keperawatan dalam memberikan asuhan keperawatan pada intensitas nyeri pasien gastritis.

\section{METODE}

Penelitian ini merupakan penelitian kuantitatif dengan desain penelitian yang digunakan adalah quasi experiment dengan pendekatan Pre and Post Test Group design. Penelitian ini dilakukan pada bulan Juni sampai dengan Agustus 2018. Pengumpulan data di Ruang Bedah Rumah Sakit Nene Mallomo Kabupaten Sidrap dilaksanakan setiap pagi mulai tanggal 2 Juni 2018 sampai dengan 25 Agustus 2018. Populasi dalam penelitian ini adalah semua penderita gastritis yang ada di Ruang Bedah Rumah Sakit Nene Mallomo Kabupaten Sidrapsebanyak 299 orang. Teknik pengambilan sampel diambil dengan cara consecutive sampling. Instrument yang digunakan dalam penelitian ini adalah lembar observasi.

Pengumpulan data dilakukan menggunakan metode pengukuran langsung intensitas nyeri responden dengan cara menilai tingakat nyeri berdasarkan lembar intrument Numeric Rating Scale (NRS). Hasilnya dihitung menggunakan skala rasio dalam satuan NRS. Analisa data yang digunakan adalah analisa univariat untuk melihat distribusi frekuensi dan analisa bivariat menggunakan uji $\mathrm{T}$ dependen (Paired $T$ test) dengan nilai kemaknaan atau alfa $(\alpha)=0,05$.

Penelitian ini menggunakan metode pengukuran secara berulang kali, dimana peneliti terlebih dahulu melakukan pengukuran terkait nyeri (pre test) kemudian memberikan intervensi terkait terapi dzikir dengan mendengarkan suara dzikir menggunakan airphone selama 15 menit. Setelah pemberian intervensi, peneliti kembali mengukur intensitas nyeri (posttest) dengan lembar instrument NRS.

Penelitian ini telah melewati kaji etik penelitian di Komisi Etik Penelitian STIKES Muhammadiyah Sidrap dengan nomor 274/Kep/II.3.AU/F/2018. 
HASIL

Tabel 1. Distribusi Frekuensi Intensitas Nyeri Sebelum dan Setelah Intervensi Terapi Dzikir

\begin{tabular}{|c|c|c|}
\hline Intensitas Nyeri & Frekuensi & $\%$ \\
\hline \multicolumn{3}{|c|}{ Intensitas Nyeri Sebelum Intervensi } \\
\hline Nyeri Sedang (4-7) & 12 & 26,7 \\
\hline Nyeri Berat $(8-10)$ & 33 & 73,3 \\
\hline \multicolumn{3}{|c|}{ Intensitas Nyeri Setelah Intervensi } \\
\hline Nyeri Ringan (1-3) & 18 & 40,0 \\
\hline Nyeri Sedang (4-7) & 27 & 60,0 \\
\hline
\end{tabular}

Tabel 2. Perbedaan Rerata Intensitas Nyeri Sebelum dan Setelah Intervensi Terapi Dzikir

\begin{tabular}{lcccc}
\hline \multicolumn{1}{c}{ Variabel } & n & Mean & SD & $\begin{array}{l}\text { Min- } \\
\text { Max }\end{array}$ \\
\hline $\begin{array}{l}\text { Pre Intensitas } \\
\text { Nyeri }\end{array}$ & 45 & 8,00 & 1,000 & $7-10$ \\
\cline { 1 - 3 } $\begin{array}{l}\text { Post Intensitas } \\
\text { Nyeri }\end{array}$ & 4,933 & 0,937 & $3-6$ \\
\hline
\end{tabular}

Tabel 3. Pengaruh Terapi Dzikir Terhadap Intensitas Nyeri pada Pasien Gastritis

\begin{tabular}{lccccccc}
\hline \multicolumn{1}{c}{ Variabel } & $\mathbf{n}$ & Selisih Mean & SE & $\mathbf{t}$ & df & $\begin{array}{c}\text { Min- } \\
\text { Max }\end{array}$ & $\boldsymbol{p}$ \\
\hline $\begin{array}{l}\text { Pre-Post } \\
\text { Intensitas Nyeri }\end{array}$ & 45 & 3,066 & 0,233 & 13,108 & 44 & $\begin{array}{c}2,6- \\
3,6\end{array}$ & 0,000 \\
\hline
\end{tabular}

\section{PEMBAHASAN}

\section{Intensitas Nyeri sebelum Intervensi}

Berdasarkan tabel 1 menunjukkan bahwa dari 45 responden, nyeri terbanyak adalah nyeri dengan skala 8-10 (nyeri berat) sebanyak 33 $(73,3 \%)$ responden dan nyeri terendah adalah nyeri dengan skala 4-7 sebanyak $12(26,7 \%)$ responden. Hal ini ditandai dengan hasil observasi yang dialami oleh responden yang merasakan nyeri sedang menyatakan mengeluh sakit pada bagian abdomen, ekspresi wajah responden meringis disertai dengan gelisah dan responden masih dapat berkomunikasi dan menunjukkan lokasi nyeri sedangkan responden nyeri dengan skala 8-10 ditandai dengan pernyataan verbal responden meringis, berkeringat, pucat, responden mengalami imobilisasi, responden hanya dapat menunjukkan lokasi nyeri dan tidak berkomunikasi.

Penelitian ini sejalan dengan penelitian (Budiyanto, Ma'rifah, \& Susanti (2015) diperoleh rata-rata nyeri responden sebelum diberikan perlakuan adalah 7,8 atau nyeri berat. Nyeri yang dialami seorang responden setelah perlakuan adalah karena efek dari pemberian terapi secara berulang akan menimbulkan rasa nyaman yang pada akhirnya akan meningkatkan toleransi persepsi dalam menurunkan rasa nyeri yang dialami.

\section{Intensitas Nyeri setelah Intervensi}

Berdasarkan tabel 2 menunjukkan bahwa dari 45 responden, nyeri terbanyak adalah nyeri dengan skala 4-7 (nyeri sedang) sebanyak 27
$(60,0 \%)$ responden dan nyeri terendah adalah nyeri dengan skala 1-3 (nyeri ringan) sebanyak $18(40,0 \%)$ responden. Hal tersebut menunjukkan setelah pemberian terapi dzikir terdapat pertambahan jumlah responden yang mengalami nyeri sedang dan responden dengan nyeri ringan menjadi 18 responden.

Pemberian terapi dzikir dilakukan 5-6 jam setelah pemberian terapi obat sebagai pendamping atau kegiatan mandiri perawat, dari observasi respon nyeri klien yang menunjukkan perubahan respon nyeri berupa kenyamanan dan nyeri berkurang. Penurunan nyeri timbul karena adanya kemampuan sistem saraf untuk mengubah berbagai stimulus mekanik, kimia, termal dan elektris menjadi potensial aksi yang dijalarkan ke sistem saraf pusat. Stimulus mekanik yaitu pemberian terapi dzikir hal ini dikarenakan ini merupakan suatu bentuk asuhan keperawatan, yang dalam hal ini perawat mengajarkan kepada klien bagaimana cara melakukan teknik terapi dzikir ini dengan baik dan dapat menurunkan intensitas nyeri.

Penelitian ini sejalan Kuswandari (2016) menyatakan bahwa dengan pemberian intervensi terapi dzikir dapat menurunkan intensitas nyeri, dimana hasil yang diperoleh skor rerata nyeri mengalami penurunan, dari nilai rerata 5,90 turun menjadi 4,05. Dzikir dapat dijadikan sebagai terapi non-farmakologi untuk dikombinasikan dengan terapi farmakologi sehingga skala nyeri seseorang dapat semakin dikendalikan. 
Perbedaan Intensitas Nyeri Sebelum dan Setelah Intervensi Terapi Dzikir

Berdasarkan hasil penelitian didapatkan nilai rata-rata intensitas nyeri sebelum intervensi yaitu hasil mean 8,00 , standar deviasi 1,000 , nilai minimum 7 dan nilai maximum 10 . Kemudian nilai rata-rata intensitas nyeri rata setelah intervensi didapatkan hasil mean 4,933, standar devisiasi 0,937 , nilai minimum 3 dan nilai maksimum 6.

Perbedaan nyeri sebelum dan setelah diberikan terapi dzikir terjadi karena saat seseorang menerima stimulus atau rangsangan berupa terapi dzikir, terjadi proses kognator (persepsi, informasi) dan regulator (kimiawi, saraf, endokrin) yang mempengaruhi cerebral cortex dalam aspek kognitif maupun emosi sehingga menghasilkan persepsi positif dan peningkatan relaksasi hingga $65 \%$ secara tidak langsung menjaga keseimbangan homeostatis tubuh melalui HPA Axis (sistem neuroendokrin hipotalamus yang mengatur stres).

Sistem neuroendokrin hipotalamus berfungsi untuk menghasilkan Corticotropin Releasing Factor (CRF) yang merangsang kelenjar pituari untuk menurunkan produksi ACTH (Adreno Corticotropic Hormone) menstrimulasi produksi endorphin. Endorphin merupakan polipeptida yang mengandung 30 unit asam amino yang mengikat pada reseptor opiat di otak yang memiliki efek natural analgesik kemudian menurunkan produksi kortisol dan hormon-hormon stres lainnya sehingga nyeri menurun (Wahida, 2015 dalam Rahma Yana, Sri Utami dan Safri, 2015).

Menurut penelitian (Budiyanto, Ma'rifah, \& Susanti (2015) didapatkan rata-rata nyeri responden sebelum diberikan perlakuan adalah 7,8 atau nyeri berat dan setelah perlakuan sebesar 3,3 atau nyeri ringan. Nyeri yang dialami seorang responden setelah perlakuan adalah karena efek dari pemberian terapi secara berulang akan menimbulkan rasa nyaman yang pada akhirnya akan meningkatkan toleransi persepsi dalam menurunkan rasa nyeri yang dialami.

Penelitian (Wulandini, Roza, \& Safitri (2018), terdapat perbedaan nilai rata-rata sebelum intervensis sebesar 5,3 dan setelah intervensi sebesar 4,0. Saat responden diberikan terapi sealam 15 menit sebagian responden mengatakan terapi ini menenangkan fikiran dan merasakan nyaman sehingga rasa nyeri yang dirasakan berkurang.

Efek lain yang dipengaruhi oleh terapi dzikir adalah pacuan sinyal molekul dan neurotransmitter. Otak akan memacu keluarnya neurotransmiter di otak, mengeluarkan opiat endogen yaitu endorphin dan enkefalin yang akan menimbulkan rasa senang, bahagia, euforiadan enak, sehingga dapat memperbaiki kondisi tubuh dengan respon relaksasinya (Potter \& Perry, 2010).

\section{Pengaruh Terapi Dzikir terhadap Intensitas Nyeri pada Pasien Gastritis}

Berdasarkan hasil penelitian didapatkan nilai $p=0,000$ dengan tingkat kemaknaan $p<\alpha$ $(0,05)$ yang dimana nilai $p<\alpha$, Ho ditolak dan Ha diterima yang berarti ada pengaruh terapi dzikir terhadap intensitas nyeri pada pasien gastritis di rumah sakit Nene Mallomo Kabupaten Sidrap.

Terapi dzikir dapat mempengaruhi intensitas nyeri pada pasien gastrtitis karena dalam pemberian terapi dzikir dilakukan selama 15-20 menit dan dilaksanakan 5-6 jam sebelum pasien diberikan tindakan farmakologi.

Pada penelitian ini peneliti menggunakan handphone dan earphone sebagai alat pendengar suara (dzikir) untuk mengalihkan perhatian pasien terhadap rangsangan nyeri yang diterima. Penggunaan earphone dapat membantu pasien untuk berkonsentrasi terhadap dzikir yang didengarkan sehingga menurunkan toleransi persepsi terhadap ransangan nyeri yang diterima dan membawa pasien pada keaadaan yang nyaman dan rileks.

Penelitian yang dilakukan oleh (Fajria (2014), meyatakan bahwa nyeri persalinan diukur secara langsung dengan menggunakan skala nyeri Visual Analag Scale (VAS) dengan uji mannwhitney untuk menilai perbedaan nyeri antara kelompok eksperimen dan kelompok kontrol. Hasil dari penelitian ini menunjukkan rata-rata intensitas nyeri kelompok eksperimen adalah 4,40 dan rata-rata intensitas nyeri kelompok kontrol adalah 7,10. Berdasarkan hasil uji statistik didapatkan nilai $p=0,000(p<0,05)$ yang artinya terdapat pengaruh terapi relaksasi zikir terhadap intensitas nyeri persalinan kala I fase aktif pada ibu primigravida.

Penelitian ini juga didukung oleh penelitian (Nasriati, Suryan, \& Afandi, 2015) menyatakan bahwa Meditasi dzikir sebagai bentuk relaksasi untuk menurunkan nyeri pasca operasi juga memberikan dampak terhadap penurunan intensitas nyeri pada pasien pasca operasi fraktur. Latihan meditasi dzikir dapat mengurangi rasa sakit karena merangsang keluarnya hormon beta endorphin dari dalam tubuh sebagai morphin alami. Meditasi bertujuan agar gelombang alfa menjadi dominan di otak. Jika otak berosilasi dalam wilayah alfa, banyak 
hormon kebahagiaan yaitu beta endorphin dikeluarkan.

Menurut penelitian Fadli (2017) mendapatkan hasil ada pengaruh distraksi pendengaran terhadap intensitas nyeri pada klien fraktur di Rumah Sakit Nene Mallomo Kabupaten Sidenreng Rappang mengunakan uji Wilcoxon dengan nilai $p=0,001$. Teknik distraksi dapat mengalihkan fokus perhatian pasien yang mengalami nyeri karena dapat menjadi strategi yang sangat berhasil dan mungkin merupakan mekanisme yang bertanggung jawab terhadap teknik kognitif efektif lainnya. Keefektifan distraksi tergantung pada kemampuan pasien untuk menerima dan membangkitkan input sensori.

Dzikir akan membuat seseorang merasa tenang sehingga kemudian menekan kerja sistem saraf simpatis dan mengaktifkan kerja sistem saraf parasimpatis. Allah berfirman "Orangorang yang beriman dan hati mereka menjadi tentram dengan mengingat Allah SWT (dzikrullah). Ingatlah, hanya dengan mengingat Allahlah hati menjadi tentram" (QS. Ar-Ra'du: 29). Menurut Lloyd \& Dunn (2007) relaksasi dan doa (prayer) menggunakan keterpaduan dan hubungan (interconnectedness) tubuh dan jiwa (mind and body) untuk perbaikan kesehatan, dalam arti lain pikiran dapat dilatih untuk menginisiasi saraf parasimpatik memulai perbaikan secara natural untuk menurunkan metabolisme tubuh yang terlalu tinggi, denyut nadi, kecepatan pernafasan, tekanan darah, dan

\section{DAFTAR PUSTAKA}

Budiyanto, T., Ma'rifah, A. R., \& Susanti, P. I. (2015). Pengaruh Terapi Dzikir Terhadap Intensitas Nyeri Pada Pasien Post Operasi CA Mammae. Jurnal Keperawatan Maternitas, 3(2), 90-96.

https://jurnal.unimus.ac.id/index.php/JKM at/article/view/4032/3750

Dinkes Prop. Sulsel. (2015). Profil Data Penyakit Tidak Menular. Sulawesi Selatan.

Diyono, \& Mulyanti, S. (2013). Buku Ajar Keperawatan Medikal Bedah Sistem Pencernaan (1st ed.). Jakarta: Prenada Media Group.

Fadli, F. (2017). Pengaruh Distraksi Pendengaran Terhadap Intensitas Nyeri Pada Klien Fraktur Di Rumah Sakit Nene Mallomo Kabupaten Sidenreng Rappang. Jurnal Ilmiah Kesehatan Diagnosis, 11, 135-138. http://ejournal.stikesnh.ac.id/index.php/jik d/article/view/236/124. ketegangan otot sehingga kembali normal sehingga memicu relaksasi dan kesembuhan (Kuswandari \& Afsah, 2016).

Terapi suara (dzikir) menyebabkan pelepasan endorphin oleh kelenjar pituitari, sehingga akan mengubah keadaan mood atau perasaan. Keadaan psikologis yang tenang akan mempengaruhi sistem limbik dan saraf otonom yang akan menimbulkan rileks, aman, dan menyenangkan sehingga merangsang pelepasan zat kimia yaitu endorphin. Endorphin merupakan analgesia alamiah atau subtansi sejenis morfin yang terdapat pada otak. Endorphin merupakan neuro transmitter nyeri atau senyawa kimia yang berfungsi untuk membawa rangsangan antar sel saraf yang dapat menghambat nyeri (Kozier, 2010).

Responden menyatakan bahwa setelah mendengarkan dzikir mereka mendapatkan ketenangan karena dapat mendekatkan kita kepada Allah SWT. Mendengarkan dzikir mengajarkan responden menjernihkan pikiran dan menetralkan pikiran. Dzikir dengan penuh penghayatan akan membawa indvidu berada dalam keadaan yang tenang dan nyaman.

\section{SIMPULAN}

Ada pengaruh terapi dzikir terhadap intensitas nyeri pada pasien gastritis di rumah sakit Nene Mallomo Kabupaten Sidrap.

Fajria, L. (2014). Pengaruh Terapi Relaksasi Zikir Terhadap Intensitas Nyeri Persalinan Kala I Fase Aktif Pada Ibu Primigravida. Ners Jurnal Keperawatan, 10(1), 102-110. https://doi.org/https://doi.org/10.25077/njk. 10.1.102-110.2014

Kozier, B. M. R. (2010). Fundamental Keperawatan. Konsep, Proses \& Praktik. Jakarta: EGC.

Kuswandari, R. P., \& Afsah, Y. R. (2016). Pengaruh Dzikir Untu Mengurangi Skala Nyeri pada Ibu Post Sectio Caesarea. Jurnal Keperawatan, 3-19.

Lloyd \& Dunn. (2007). Mind-Body-Spirit Medicine: Interventions and Resources. http://www.ncbi.nlm.nih.gov/pubmed/1801 9327.

Nasriati, R., Suryan, L., \& Afandi, M. (2015). Kombinasi Edukasi Nyeri dan Meditasi Dzikir Meningkatkan Adaptasi Nyeri Pasien 
Pasca Operasi Fraktur. Muhammadiyah Journal of Nursing, 59-68. http://repository.umy.ac.id/bitstream/handl e/123456789/5841/11. Naskah PublikasiSekar.pdf?sequence $=12 \&$ isAllowed $=\mathrm{y}$

Nuratif, A. H., \& Kusuma, H. (2015). Aplikasi Asuhan Keperawatan Berdasarkan Diagnosa Medis \& NANDA, NIC-NOC (Revisi Jil). Jogjakarta: MediAction.

Potter, P. A., \& Perry, A. G. (2010). Fundamental of Nursing. Jakarta: EGC.

Rahma Yana, Sri Utami, dan Safri. 2015. Efektivitas Terapi Murottal Al-Qur'an Terhadap Intensitas Nyeri Persalinan Kala I Fase Aktif. JOM Vol. 2 No. 2

Rudyana, H., \& Bangun, A. V. (2014). Pengaruh Dzikir (Asmaul Husna) Terhadap Skala Intensitas Neri Pasien Post Operasi Laparatomi. Jurnal Kesehatan Kartika, 9(2), 54-63.

http://repository.stikesayani.ac.id/index.ph
p/Jurnal_Kartika/article/view/142

Wahyuni, S. D., Rumpiati, \& Lestariningsih, R. E. M. (2017). Hubungan Pola Makan dengan Kejadian Gastritis Pada Remaja. Journal Global Health Science, 2(2), 149154.

jurnal.csdforum.com/index.php/GHS/articl e/download/100/41\%0A\%0A

Wulandini, P., Roza, A., \& Safitri, S. R. (2018). Efektifitas Terapi Asmaul Husna Terhadap Penuruan Skala Nyeri Pada Pasien Fraktur. Jurnal Endurance, 3(2), 375-382. https://doi.org/http://doi.org/10.22216/jen. v3i2.3116.

Yuniarti, Darwin, \& Huda, N. (2016). Efektifitas Teknik Relaksasi Napas Dalam dan Dzikir Terapi Terhadap Nyeri Post Op Katarak. Jurnal Online Mahasiswa (JOM) Bidang Ilmu Keperawatan. Universitas Riau. https://jom.unri.ac.id/index.php/JOMPSIK/ article/viewFile/19237/1...\%0A\%0A. 